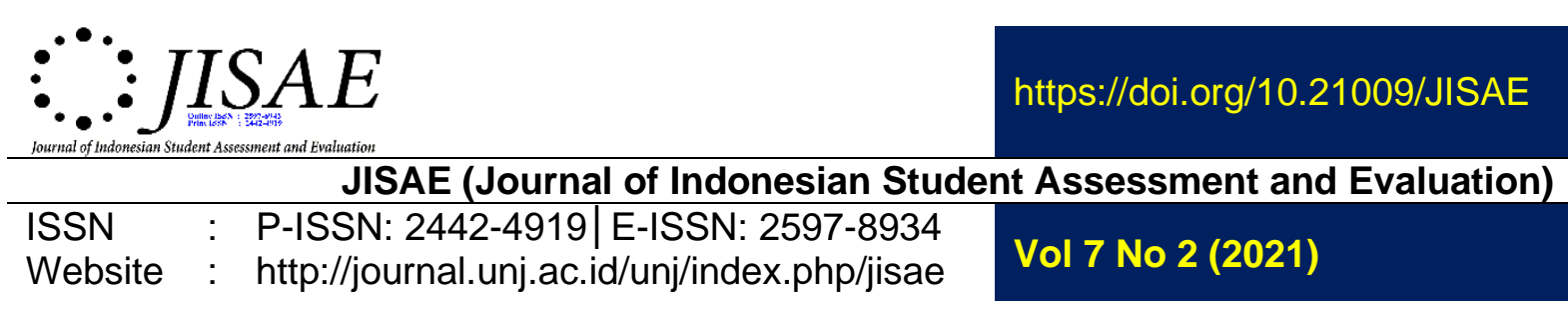

\title{
CONSTRAINTS TO EFFECTIVE CONTINUOUS PROFESSIONAL DEVELOPMENT OF TEACHERS IN GOVERNMENT SECONDARY SCHOOL IN FCT
}

\begin{abstract}
Gregory Deborah ${ }^{1}$
Federal University Wukari, Nigria
\end{abstract}

Ogunode Niyi Jacob²

Federal University Wukari, Nigria

Jegede Deborah ${ }^{3}$

Federal University Wukari, Nigria

Address for Correspondence:

1magitdeby@yahoo.com

20gunodejacob@gmail.com

3Jegededeborah30@gmail.com

\section{ABSTRACT}

The study examined the constraints to effective continuous professional development of teachers in Government Secondary School in F.C.T. This study was conducted in Federal Capital Territory, Abuja, Nigeria. Survey designed was used for the study. The study used 220 respondents. Simple random and stratified methods were used to select the population for the study. Questionnaire was used for collection of data. The questionnaire was tagged" Constraints to Effective Continuous Professional Development of Teachers in Government Secondary School Teacher Questionnaire [CECPDTGSSTQ]". The questionnaire contained two section with nine item sub-questions. The section $A$ : collected information for bio-data while section B collected information on the subject matter. The section (B) was designed to have Yes and NO. The researcher employed the services of a research assistant. The research assistant went to the various schools to administer the questionnaire. The data collected were analyze with simple percentage. The data collected, analyzed and computed led to the conclusion that inadequate funding, lack of political will, institutional corruption, inadequate data on teacher training need gap, political instability, unstable educational policies, favoritism, improper planning of staff development programme and high cost of training are the constraints to effective teacher development in Secondary Schools in Federal Capital Territory, Abuja. From the above conclusion, the paper hereby recommended that the government should increase the funding of professional development programme of secondary school teachers in FCT.

Keyword: Constraints, Effective, Secondary Schools, Professional Development, Education

\section{INTRODUCTION}

Secondary school education is an education designed for children that are leaving basic education. Aiyedun (2020) stated that secondary school education is post-basic education that advance with specialization of field. Secondary school education is the ladder between the basic education and the higher education. The 
objective of secondary school education include; to provide educational opportunity for children leaving primary school education, to provide for tertiary education students.

The realization of the objectives of secondary school education depend on the quality of educational resources available. The educational resources include the human and materials resources. The human resources include the non-teaching staff, the teachers and the school administrators. The teacher is one of the key member of the educational institutions. The teacher is a professional individual that have undergone different training in teaching and have been tested in examination in a higher education and com out successful. The teacher is a trained individual that is saddle with the responsibilities of teaching and carrying out other academic activities in an educational institutions. The teacher prepare the lesson, organizes the instructional resources and deliver the lesson. The teacher assess and evaluate the students in tests and examinations (Ojelade, Aregbesola, Ekele \& Aiyedun, 2020).

The effectiveness of the teacher depends on continuous development of professional programmes. For the teacher to be abreast and up to date in his field of study, he need continuous professional development programme constantly. Continuous professional development programme or capacity development programme are programmes designed to improve the capacity of employee in an organization. Capacity development programme is a special programme within an organization design to meeting the capacity gap of an employee in an organization (Olatunde-Aiyedun \& Ogunode, 2021a).

In the educational sector capacity development programme is called continuous professional development programme or teacher professional development programme. Teacher professional development programme is a programme developed for the teacher in all the educational institutions with the aims of improving their capacity in delivering of lesson, mastery of subject, classroom management and teaching methodology. Teacher professional development programme is designed purposely for the teacher professional development (Olatunde-Aiyedun \& Ogunode, 2020).

The scope of capacity development programme of teachers includes; pedagogical skills development of the teachers, improvement of teachers' classroom management skills, mastery of subjects matter and recording keeping skills. The teacher capacity development programme can be realized through seminar, conferences, workshops, orientation and in-service training. The aim is to help them improve their classroom teaching for effective learning of students. Impact is the net effect on the teaching learning process which was measured on the basis of teaching of those whose capacity were built in different projects in relation to their teaching in classrooms that was observed (Olatunde-Aiyedun \& Ogunode, 2021b).

The importance of teacher development for secondary school teachers includes: it aids teachers to deliver academic services very well, it boosts teacher confidence and increase his/her commitment to work; it helps to keep teachers with current issues and development in curriculum changes and reforms, it upgrade the teachers' knowledge and skills in teaching methodologies and it helps teacher to be effective and efficient in resources management in education (Olatunde-Aiyedun, EyiolorunseAiyedun \& Ogunode, 2021).

Teachers that constantly go for professional development programme performed well and discharge their responsibilities well. Research has recognized the import of teachers' professional development as crucial to changing classroom practices, improving schools and bettering pupils' learning outcomes (Borko, 2004). 
Goodall, Day, Lingsay, Muiji and Harris (2005); and Osiesi (2020) noted that teacher professional development programs are learning experiences and activities which are intended to immensely benefit the populace at large both directly and indirectly; as well as aiding teachers' competencies. Therefore, making available opportunities for teachers' intensive and continuous professional development programme at all levels of education (primary school teachers, most especially) will enhance quality teaching and learning (Osiesi, 2020). The implementation of the teacher professional development programme in Nigerian educational institutions is facing many challenges especially at the secondary school education level. In line with the above, this study is aimed to find out constrains to effective continuous professional development of teachers in Government Secondary School Teacher in F.C.T.

\section{Research Objective}

The aim of this study is to find out the constraints to effective continuous professional development of teachers in Government Secondary School Teacher in F.C.T. Specific objective includes:

1. To find out the constraints to effective continuous professional development of teachers in Government Secondary School Teacher in F.C.T.

\section{Research Question}

The following research question where generated to guide this study:

1) What are the constraints to effective continuous professional development of teachers in Government Secondary School Teacher in F.C.T.?

\section{Literature Review}

There are many investigations on teacher professional development programme across different countries by different researchers. In Nigeria, Peretomode and Chukwuma in (2013) did a study that examined the relationship between manpower development and lecturers' productivity in tertiary institutions in the Delta State of Nigeria. The results led to the conclusion that manpower development enhances lecturers' productivity irrespective of gender, faculty and type of institution, although these predictor variables could explain only eight percent of lecturers' productivity in institutions of higher learning in Delta State of Nigeria.

Mahdi (2020) did a research project with a case study conducted to investigate "Teachers' perceptions of CPD effectiveness in Higher Education in Kurdistan". This will show the impact of CPD at the institutional and individual level, as well as to highlight the current CPD policies at the selected organization. The findings indicate that CPD has a crucial role in the delivery of teaching. However, practitioners note that the sector dynamic is not organized. In other words, findings revealed a mismatch between individual needs and CPD policy, for instance, lack of ICT (Olatunde-Aiyedun, Ogunode \& Eyiolorunse-Aiyedun, 2021).

Basil , Felix , and Eno (2013) carried out a study that examined university lecturers' participation in capacity building programmes in south-south Nigeria and its implication for sustainable development. It focuses on the extent of lecturers' participation in workshops, seminars, conferences, ICT training and mentoring aspects of capacity building programmes. Findings revealed that university lecturers participate mostly in conferences than any other capacity building programme. Lecturers' participation in capacity building programmes is significantly low with respect to workshops, seminars, conferences, ICT training and mentoring. There is no significant difference between male and female lecturers' participation in capacity building programmes. It was recommended that enabling environment should be 
provided whereby university lecturers are encouraged to participate fully in capacity building programmes (Olatunde-Aiyedun, Eyiolorunse-Aiyedun \& Ogunode, 2021).

Bernadette \& Ukaegbu, (2017) did a study on impact of poor implementation of welfare policies on training and development on the performance of academic staff in selected federal Universities in South-South Nigeria was carried out to examine the extent to which poor implementation of welfare policies on training and development impacts on the performance of workers in the selected Federal universities in SouthSouth Nigeria. The study discovered that, whereas there are good welfare policy statements in the study area, the level of implementation of these policies were poor. Furthermore, over $90 \%$ of the respondents insisted that full implementation of welfare policies would have positive impact on workers" performance to a very large extent. The results further indicated that there have been very few in-house and outside training programmes in the study area. A total of $87 \%$ of respondents agreed that poor level of implementation of welfare policies on training and development is a source of discouragement which have negatively affected academic performance of both teaching and non-teaching staff and have led to poor service delivery in our Universities (Olatunde-Aiyedun \& Ogunode, 2021a). .

Amir , Mohammad \& Habibunnabi (2016) conducted that a study attempted to find out the impact of capacity building of teachers of Government Boys' Primary Schools on classroom teaching. The objectives of the study were to find out the strengths and weaknesses of the capacity building initiatives for professional development of teachers in district Swat. The results revealed that Head Masters could play more effective role for school effectiveness by developing clear vision; providing instructional feedback to teachers; effective monitoring and supervisory mechanism; setting a democratic environment conducive to teaching learning process and involving the stakeholders in decision-making. The results of the study further indicated that school effectiveness owed itself to capable Head Masters, committed staff, non-political intervention, a procedure of incentives and disincentives, positive feedback to teachers and last, but not the least, a continuous instructional supervision of what happened in classroom. Walton (2005) studied the influence of workshops on teachers' job performance and reported a significant influence of workshops on teachers' output. The researcher concluded that teachers should be provided with opportunities to attend workshops to acquire and update their skills for high productivity.

Dolores and Ernest (2018) stated that, poor performance of teachers was due to lack of frequent in-service training, lack of teaching and learning materials, lack of incentives and motivation, and improper supervision. It is therefore, recommended that Ghana Education Service should improve upon its in-service training and development policy to be consistent with the needs of teachers. More so, periodic learning needs assessments should be conducted before training programmes are designed for teachers.

Igwe and Ibara, (2019) noted that: teachers' capacity building on curriculum development has a strong positive relationship with the students learning outcomes; teachers' capacity building on information and communication technology (ICT), has a strong positive relationship with the students learning outcomes, and teachers" capacity building in students' assessment has a strong positive relationship with the students" learning outcomes. The study concluded that teachers" capacity building in curriculum development, information and communication technology and teachers" capacity building on students' assessment will enhance teachers' competencies in 
teaching which will translate into students' achievement in learning in junior public secondary schools in Rivers State.

\section{METHOD}

The objective of this was to find out the constraints to effective continuous professional development of teachers in Government Secondary School in F.C.T. This study was conducted in Federal Capital Territory, Abuja, Nigeria. The study cover all the six area councils. Two secondary schools was selected from each area council of FCT. Twelve government secondary schools in FCT was used for the study. Survey designed was used for the study. The study used 220 respondents. The respondents were teachers. Simple random and stratified methods was used to select the population for the study. This implies that ten teachers from the twelve government secondary schools were sampled for the study. This sample sampling method was drawn in such a way that male and female teachers were represented in the study. Questionnaire was used for collection of data for the study. The questionnaire was tagged" Constraints To Effective Continuous Professional Development of Teachers in Government Secondary School Teacher Secondary School Teacher Questionnaire [CECPDTGSSTQ]". The questionnaire contained two section with nine item subquestions. The section A: collected information for bio-data while section B collected information on the subject matter. The section B was designed to have Yes and NO. Two lecturers were consultant to validate the questionnaire while the trial test was conducted in neighboring state where forty teachers. The teachers were administered and re-administered to the same questions to after two weeks intervene. The scores obtained were analysed using Cronbach Alpha Method. The results gave rise to a reliability coefficient which ranged from 0.66 to 0.82 . The resulted collected was positive implying the instrument was reliable. The researcher employed the services of a research assistant. Research assistant was engaged to help in collection of data with questionnaire. The distribution and returning of questionnaire in various school recorded hundred percent returns rate. The researchers used simple percentage to analyze the data collected in the study.

\section{Analysis and Results}

Research question: What are the constraints to effective continuous professional development of teachers in Government Secondary School Teacher in F.C.T?

Table 1: Constraints to Effective Continuous Professional Development of Teachers in Government Secondary School Teacher in FCT.

\begin{tabular}{lcccccc}
\hline Constraints & $\mathbf{F}$ & Yes & $\mathbf{\%}$ & $\mathbf{F}$ & $\mathbf{\%}$ & \\
& 182 & 82.72 & 38 & 17.28 & 220 \\
1) Inadequate funding & 174 & 79.0 & 46 & 21.0 & 220 \\
2) Lack of political will & 190 & 86.36 & 30 & 13.64 & 220 \\
3) Institutional corruption & 169 & 76.81 & 51 & 23.19 & 220 \\
4) Inadequate data on teacher training & & & & & \\
need gap & 147 & 66.81 & 73 & 33.19 & 220 \\
5) Political instability & 143 & 65.0 & 87 & 35.0 & 220 \\
6) Unstable educational policies & 156 & 65.4 & 64 & 32.1 & 220 \\
7) Favourite & 198 & 90.0 & 22 & 10.0 & 220 \\
8) Improper plan of staff development & & & & & \\
Programme & 183 & 83.18 & 47 & 16.92 & 220 \\
9) High cost of training & & & & &
\end{tabular}


From table item one revealed that $82.72 \%$ of the respondents agreed that inadequate funding is a constraint to effective teachers continuous development programme in government secondary schools in FCT while 19.28 disagreed that inadequate fund is a constraint. This implies that the budgetary allocation for the professional development of teachers in FC T secondary schools in inadequate.

Table one item two disclosed that $79.0 \%$ of respondents agreed that lack of political will from the government to support teachers professional development programme is a constraint to effective teachers professional development programme of secondary school teachers in FCT while $21 \%$ of the respondents disagreed that lack of political will from the government to support teachers professional development programme is not a constraint to effective teachers professional development programme of secondary school teachers in FCT. This means that lack of political will from the government to support teachers professional development programme is a constraint to effective teachers' professional development programme of secondary school teachers in FCT

Table one item three showed that $86.36 \%$ of the teachers agreed that institutional corruption is a constraint to effective teachers continuous development programme in government secondary schools in FCT while 13.64 of the respondents disagreed that institutional corruption is not a constraint to effective teachers continuous development programme in government secondary schools in FCT. This implies that institutional corruption is a constraint to effective teachers continuous development programme in government secondary schools in FCT.

Result from table 1 item four disclosed that $76.81 \%$ of the respondent agreed that inadequate data on teacher training need gap is a constraint to effective teacher development in FCT while $23.19 \%$ of the respondents disagreed that inadequate data on teacher training need gap is a constraint to effective teacher development in FCT. This means that the majorities of the respondents agreed that inadequate data on teacher training need gap is a constraint to effective teacher development in FCT.

$66.81 \%$ of the respondents agreed on table one item five that political instability is a constraint to effective teacher development in FCT while $33.19 \%$ of teachers disagreed that political instability is a constraint to effective teacher development in FCT. This implies that majorities the participant agreed that political instability is a constraint to effective teacher development in FCT.

Table one item six showed that $65 \%$ and $35 \%$ of the respondents both agreed and disagreed that unstable educational policies is a constraints to effective teacher development in FCT. This result revealed that majorities agreed that unstable educational policies is a constraints to effective teacher development in FCT.

From table one item seven revealed that $82.72 \%$ of the respondents agreed that favourism is a constraint to effective teachers continuous development programme in government secondary schools in FCT while 19.28 disagreed that inadequate fund is a constraint. This implies that the favourism is a constraint to effective teachers development programme in FC T government secondary schools.

Result from table 1 item eight disclosed that $90 \%$ of the respondent agreed that improper plan of staff development programme is a constraint to effective teacher development in FCT secondary schools while $10 \%$ of the respondents disagreed that improper plan of staff development programme is a constraint to effective teacher development in FCT secondary schools. This means that the majorities of the respondents agreed that improper plan of staff development programme is a constraint to effective teacher development in FCT government secondary schools. 
Table one item nine showed that $83.18 \%$ and $16.82 \%$ of the respondents both agreed and disagreed that high cost of training is a constraints to effective teacher development in FCT. This result revealed that majorities agreed that high cost of training is a constraints to effective teacher development in FCT government secondary schools.

\section{RESULTS AND DISCUSSION}

From table item one showed that the respondents agreed that inadequate funding is a constraint to effective teachers continuous development programme in government secondary schools in FCT. This result confirms Olatunde-Aiyedun and Ogunode (2021b) study that inadequate funding of staff development programme is responsible for ineffective teacher development programme in many educational institutions. This submission also agreed with the conclusion of Ogunode and Aiyedun, T.G. (2020) stated that the government inability of funding education is responsible for poor staff development programme in the Nigerian educational institutions.

Table one item two disclosed that respondents agreed that lack of political will from the government to support teachers professional development programme is a constraint to effective teachers professional development programme of secondary school teachers in FCT. This result is in agreement with the finding of Ogunode (2020) who concluded that the lack of political will of the government at every levels of government to allocated adequate funds for the development of teachers is responsible for the poor quality of education.

Table one item three showed that teachers agreed that institutional corruption is a constraint to effective teachers continuous development programme in government secondary schools in FCT .

Kemi (2013) and Abdul (2014) all agreed that institutional corruption in the various agencies of government is responsible for poor implementation of educational programme include teacher professional development programme.

Result from table 1 item four disclosed that the respondent agreed that inadequate data on teacher training need gap is a constraint to effective teacher development in FCT. This result is in agreement with the submission of Ogunode (2020) who concluded that one of the programme facing the Nigerian educational system is lack of adequate data on every educational input.

The respondents agreed on table one item five that political instability is a constraint to effective teacher development in FCT. This result supported the submission of Abdul (2014) who observed that political instability have done more harm to the Nigerian educational system because educational programme and policies are often change whenever there is a change in government or administration. This implication is that many educational programme will be abandon and new one start.

Table one item six showed that respondents agreed that unstable educational policies is a constraints to effective teacher development in FCT. This result collaborates with Ogunode (2020) who submitted that in Nigeria, unstable educational policies is not a new thing, government at every level changes policies whenever there is a change in government and this affects the entire educational programme.

From table one item seven revealed that respondents agreed that favourism is a constraint to effective teachers continuous development programme in government secondary schools in FCT. Ogunode (2020) submitted that poor internal administration and favourism is challenge to effective professional development programme at the primary schools in Nigeria. 
Result from table 1 item eight disclosed that respondent agreed that improper plan of staff development programme is a constraint to effective teacher development in FCT secondary schools. Ogunode (2020) submitted that poor planning of education is responsible for ineffectiveness of educational programme like supervision of education and staff development programme.

Table one item nine showed that respondents agreed that high cost of training is a constraints to effective teacher development in FCT. Adeola (2014) submitted that the high cost of staff development programme and other educational input is the cause of poor teacher continuous professional development programme in Nigeria.

\section{CONCLUSION, IMPLICATION OF THE STUDY}

The aim of this study was to find out the constraints to effective continuous professional development of teachers in Government Secondary School Teacher in F.C.T. The specific objectives was to find out the constraints to effective continuous professional development of teachers in Government Secondary School Teacher in F.C.T. The data collected, analyze and computed led to the conclusion that inadequate funding, lack of political will, institutional corruption, inadequate data on teacher training need gap, political instability, unstable educational policies, favourite, improper plan of staff development programme and high cost of training are the constraints to effective teacher development in Secondary Schools in Federal Capital Territory, Abuja.

\section{Recommendations}

From the above conclusion, the paper herby recommended the following:

a) The government should increase the funding of professional development programme of secondary school teachers in FCT;

b) The government should development a road map for staff development programme for secondary school teachers in FCT; and

c) The government should fight all the institutional corruption within the ministries and department of education. This will help to ensure that funds allocated for staff development programme are effective and efficiently used.

\section{REFERENCES}

Aiyedun, T.G. (2020). Effect of animation teaching strategy on secondary school students' achievement, retention and interest in climate change in Lokoja, Kogi State. International Journal of Trend in Scientific Research and Development (IJTSRD), 4 (3) 944-949. https://www.ijtsrd.com/papers/ijtsrd30740.pdf

Aiyedun, T.G. \& Ogunode, N.J. (2020). Effect of COVID-19 on academic program in universities in Nigeria. Electronic Research Journal of Engineering, Computer and Applied Sciences, 2, 193-201.

https://www.researchgate.net/publication/346966789 Effect of Covid19 pandemic on academic programme of universities in Nigeria

Amir H, Mohammad I \& Habibunnabi2 (2016) Impact of Capacity Building of Teachers of Government Boys" Primary School on Class Room Teaching in District Swat, Pakistan. Elixir Social Studies 91,38252-38254 38252

Borko, H. (2004). Professional development and teacher learning: Mapping the terrain. Educational Researcher, 33(8), 3-15.

Bernadette C.N \& Ukaegbu, O (2017) Impact of Poor Implementation of Welfare Policies on Training and Development on the Performance of Academic Staff in Selected Federal Universities in South-South Nigeria. International Journal 
of Scientific Research and Management (IJSRM) Volume(5)Issue (12)|Pages 7718-7729

Basil A. A, Felix D. N, Eno E.E (2013) Lecturers' Participation in Capacity Building Programmes in South-South Nigeria: Implications for Sustainable Development. Makerere Journal of Higher Education. 4(2), $279-292$

Dolores M., H \& Ernest C., W. (2018). Enhancing Teachers' Performance through Training and Development in Ghana Education Service (A Case Study of Ebenezer Senior High School). Journal of Human Resource Management, $6(1), 1-8$.

Goodall, J., Day, C., Lindsay, G., Muijis, D. \& Harris, A. (2005). Evaluating the impact of continuing professional development (CPD). Research report RR659. The University of Warwick.

Igwe, M. O., \& Ibara, E. C. (2019). Teachers Capacity Building Skills and Students Learning Outcomes in Junior Public Secondary Schools in Rivers State. International Journal of Scientific Research in Education, 12(2), 290-305. Retrieved [DATE] from http://www.ijsre.com.

Mahdi, A.Q. (2020). Teachers' perception of continuous professional development "cpd" effectiveness in higher education in kurdistan. Indonesian Journal of Educational, 7 (1), 29-39.

Ogunode, N.J. (2020). Effective Capacity Development Programme for Educational institutions. Kano D. C. Bubal Printing Press.

Ogunode, N.J. \& Aiyedun, T.G. (2020). Administration of science programme in Nigerian higher institutions: issues, challenges and way forward. Middle European Scientific Bulletin, 6, 94-99.

https://www.researchgate.net/publication/346653519 Administration of scien ce programme in Nigeria's higher institutions issues challenges and way forward? sg=WXqpyO7WFiLRU9HJYoxtyk177dpVprKEaYzc2GZgf7OL9CyMY564JEs KfFHD8uaKJh12bWA449Ylag5I9d9wu74 p0v5uEAhcqRIC.5LZX7 yYMloloXosECNpqeFvTI1U8PNFaakPyBBxf2XJPPT2ngLDxnRhsrld0pHgWRRs 673PfJ8fo2N0FOBw

Ogunode N.J, Eyiolorunse-Aiyedun, C.T. \& Olatunde-Aiyedun, T.G. (2021). Educational planning in Nigeria during covid-19: problems and way forward. Academicia Globe: Inderscience Research, 2(07), 137-147. https://doi.org/10.17605/OSF.IO/RM4SY

Ojelade, I. A., Aregbesola, B. G., Ekele, A., \& Aiyedun, T. G. (2020). Effects of AudioVisual Instructional Materials on Teaching Science Concepts in Secondary Schools in Bwari Area Council Abuja, Nigeria. The Environmental Studies Journal (TESJ), 3, (2) $52-61$.

https://researchersjournal.org/effects-of-audio-visual-instructional-materialson-teaching-science-concepts-in-secondary-schools-in-bwari-area-councilabuia-nigeria/

Olatunde-Aiyedun, T.G., Eyiolorunse-Aiyedun, C.T. \& Ogunode, N.J. (2021). Post covid-19 and digitalization of University lecturers in Nigeria. Middle European Scientific Bulletin, 11(1). http://cejsr.academicjournal.io/index.php/journal/article/view/488

Olatunde-Aiyedun, T.G. \& Ogunode, N.J. (2021a). Shortage of professional science and environmental education teachers in Nigeria. Asian Journal of Science Education, 3 (1), 1-11. 
https://www.researchgate.net/publication/350819014 Shortage of Professional Sci ence and Environmental Education Teachers in Nigeria

Olatunde-Aiyedun, T.G. \& Ogunode, N.J. (2021b). School Administration and effective teaching methods in Science Education in Nigeria. International Journal on Integrated Education, 4 (2), 145- 161. 10.13140/RG.2.2.11502.54080

or https://doi.org/10.17605/OSF.IO/S6N2Q

Olatunde-Aiyedun, T.G. \& Ogunode, N.J. (2021a). School Administration and effective teaching methods in Science Education in Nigeria. International Journal on Integrated Education, 4 (2), 145- 161. 10.13140/RG.2.2.11502.54080

Olatunde-Aiyedun, T.G. \& Ogunode, N.J. (2021b). Shortage of professional science and environmental education teachers in Nigeria. Asian Journal of Science Education, 3 (1), 1-11.

https://www.researchgate.net/publication/350819014 Shortage of Professional Sci ence and Environmental Education Teachers in Nigeria

Olatunde-Aiyedun, T.G., Ogunode, N.J. \& Eyiolorunse-Aiyedun, C.T. (2021). Assessment of virtual learning during covid-19 lockdown in Nigerian public universities. Academicia Globe: Inderscience Research, 2 (5) 159-175.

https://agir.academiascience.org/index.php/agir/article/view/132

Osiesi, M P. (2020). Import of professional development programmes for primary school teachers in Nigeria. International Journal on Integrated Education. 3 (6), 111-117

Peretomode, V.F\& Chukwuma, R.A (2013) Manpower development and lecturers' productivity in tertiary institutions in Nigeria. European Scientific Journal, 8 (13).

Walton, D. (2005). Effective Secondary Classroom Practice. Washington D. C. Government Printing Press. 